\title{
Functional role of a novel cis-acting element (GAGA box) in human type-1 angiotensin II receptor gene transcription
}

\section{B D Wyse, S L Linas and T J Thekkumkara}

Division of Renal Diseases and Hypertension, Department of Medicine, University of Colorado Health Sciences Center, Denver, Colorado 80262, USA

(Requests for offprints should be addressed to T J Thekkumkara, Department of Medicine, C281, University of Colorado Health Sciences Center, 4200 East Ninth Avenue, Denver, Colorado 80262, USA; Email: thomas.thekkumkara@UCHSC.edu)

\begin{abstract}
$\mathrm{GH} /$ growth factors have been shown to increase angiotensin type 1 receptor expression. In the present study we determined the cis-acting regulatory region controlling $\mathrm{GH}$-induced transcription of the human type-1 angiotensin receptor $\left(\mathrm{hAT}_{1}\right)$. In human proximal tubule cells transfected with a chloramphenicol acetyl transferase (CAT) reporter plasmid under the control of the $\mathrm{hAT}_{1}$ promoter, GH induced CAT activity. Serial deletions of the $\mathrm{hAT}_{1}$ promoter region indicated that an area between $-314 \mathrm{bp}$ and $-70 \mathrm{bp}$ upstream of the $5^{\prime}$-end of the cDNA sequence was essential for this activation to occur. Although sequence analysis identified putative multiple nuclear protein binding sites in this region, we determined that a $12 \mathrm{bp}$ sequence (5'-GAGAGGGAGGAG-3', GAGA box) located between $-161 \mathrm{bp}$ and $-149 \mathrm{bp}$ was important for GH-mediated activation. Using mobility shift assays we demonstrated increased DNA binding activity to the labeled GAGA box in
\end{abstract}

nuclear extracts treated with $\mathrm{GH}$, suggesting this sequence is a GH response element. Southwestern analysis identified an $18 \mathrm{kDa}$ GAGA box-binding protein (GAGA-BP). GH-induced activity of the GAGA-BP occurred within $2.5 \mathrm{~min}$ and reached a maximum at $5 \mathrm{~min}$. Activation did not require de novo protein synthesis. Removal of the GAGA box abolished $\mathrm{GH}$-induced transcription as well as basal transcription of the $\mathrm{hAT}_{1}$ gene. Additional studies demonstrated that epidermal growth factor, platelet-derived growth factor and insulin activate the GAGA-BP, suggesting these growth factors can also regulate the transcription of the $\mathrm{hAT}_{1}$ gene through the GAGA box. Our data show that the GAGA-BP acts as a trans-acting factor binding to the cis-acting regulatory element in the $\mathrm{hAT}_{1}$ promoter, which is necessary for the basal and growth factor(s)-mediated transcriptional activation of the hAT 1 gene.

Fournal of Molecular Endocrinology (2000) 25, 97-108

\section{INTRODUCTION}

The renin-angiotensin system (RAS) is an important regulator of many physiological functions and pathophysiological conditions, including catecholamine release, aldosterone synthesis, sodium retention and organ development as well as vascular and cardiac hypertrophy (Raizada et al. 1996). The main effector peptide of the RAS is angiotensin II (AngII). In humans, AngII actions are mediated by two pharmacologically defined cell surface receptors, angiotensin II type $1\left(\mathrm{AT}_{1}\right)$ and type 2 . In the adult kidney the $\mathrm{AT}_{1}$ receptor is the predominant subtype, which regulates hemodynamics, tubular transport and growth (Raizada et al. 1996). AngII influences renal hemodynamics by preferentially constricting the efferent arteriole thereby increasing glomerular hydrostatic pressure and glomerular filtration rate. It also acts directly through proximal tubule $\mathrm{AT}_{1}$ receptors, and indirectly through aldosterone release to increase sodium reabsorption. Therefore, under normal physiological conditions, the $\mathrm{AT}_{1}$ receptor is very important in maintaining kidney function. Factors or events that alter $\mathrm{AT}_{1}$ gene expression will therefore disrupt normal kidney function.

Initiation of mRNA synthesis is a primary control point in the regulation of gene expression. Cells respond to intra- and extracellular signals by turning specific genes on and off and by altering the extent of transcription of active genes (Maniatis et al. 1987). Although the mechanism and 
biochemical pathways involved are still largely unknown, it is clear that the initiation of mRNA synthesis requires the interaction of proteins with specific DNA sequence(s) in the gene 5 '-regulating region. In this manuscript, we address the regulation of human $\mathrm{AT}_{1}\left(\mathrm{hAT}_{1}\right)$ mRNA in the kidney at the transcriptional level. Previous studies of the transcriptional regulation of the $\mathrm{AT}_{1}$ receptor have principally utilized the rat or mouse as models (Regitz-Zagrosek et al. 1996). In those studies a variety of vasoactive peptides, hormones and growth factors have been shown to alter $\mathrm{AT}_{1}$ receptor levels by either enhancing or repressing the transcriptional activity of the gene (Guo et al. 1995, Regitz-Zagrosek et al. 1996). We investigated growth factors and, in particular, growth hormone $(\mathrm{GH})$ regulation of $\mathrm{hAT}_{1}$ gene transcription in human proximal tubule cells for several reasons. First, GH alters sodium balance and cardiovascular homeostasis in humans (Hoffman et al. 1996) and animals (Wyse et al. 1993). GH-induced changes in the rat are associated with alterations in RAS activity and, in particular, the $\mathrm{AT}_{1}$ receptor density of the kidney, adrenal and liver in vivo (Wyse et al. 1993). Secondly, in vitro, GH directly regulates rat $\mathrm{AT}_{1 \mathrm{~A}}$ receptors in primary astrocyte cultures by altering transcription (Wyse \& Sernia 1997). Finally, GH and AngII receptors are expressed in the proximal tubule, the nephron segment in which the majority of filtered sodium is reabsorbed (Mujais et al. 1986, Chin et al. 1992).

The goal, therefore, of this study was to elucidate associations between $\mathrm{GH}$ and the $\mathrm{hAT}_{1}$ gene. We demonstrate that $\mathrm{GH}$ alters the rate of transcription of the $\mathrm{hAT}_{1}$ gene through a $12 \mathrm{bp}$ (GAGA box) sequence. This GAGA box was shown to act as a bifunctional element that is necessary for both basal and $\mathrm{GH} /$ growth factor(s)-mediated activation of $\mathrm{hAT}_{1}$ transcription. We also identified a novel $18 \mathrm{kDa}$ nuclear protein that is specifically activated by $\mathrm{GH} /$ growth factor(s) and interacts with the GAGA box. Therefore, we propose that binding of $\mathrm{GH} /$ growth factor(s) to receptors activates a novel trans-acting nuclear factor which specifically binds to a cis-acting element of the promoter region of $\mathrm{hAT}_{1}$ receptor to increase its rate of transcription.

\section{MATERIALS AND METHODS}

\section{Materials}

LRCC8, an SV40-transformed human kidney proximal tubule cell line was kindly provided by Dr Lorraine Racusen (The Johns Hopkins University School of Medicine, Baltimore, MD, USA) (Racusen et al. 1997). Dulbecco's Modified Eagle's
Medium (DMEM), fetal calf serum (FCS), penicillin, streptomycin, trypsin/EDTA and lipofectamine Plus reagents were from Life Technologies (Gaithersburg, MD, USA); $\left[\alpha-{ }^{32} \mathrm{P}\right] \mathrm{dGTP}$, $\left[\alpha-{ }^{32} \mathrm{P}\right] \mathrm{dATP}$ and $\left[\alpha_{-}{ }^{35} \mathrm{~S}\right] \mathrm{dATP}$ were from DupontNew England Nuclear (Boston, MA, USA); pCAT reporter plasmids and $\mathrm{pSV}-\beta$-galactosidase expression plasmids and restriction enzymes were from Promega Co. (Madison, WI, USA); sequencing kits were from the United States Biochemical Co. (Cleveland, OH, USA); Taq polymerase was from Perkin-Elmer Co. (Norwalk, CT, USA); Tube-O Dialyzer was from Geno-Technology (St Louis, MO, USA); NICK (Sephadex G-50) columns were from Pharmacia Biotech (Uppsala, Sweden); electrophoresis reagents, human $\mathrm{GH}(\mathrm{hGH})$ and all other chemicals were from Bio-Rad (Richmond, CA, USA) and Sigma Chemical Co. (St Louis, MO, USA). MacVector 6.5 sequence analysis software was from Oxford Molecular Ltd (Madison, WI, USA) and GraphPad Prism statistical analysis software was from GraphPad Software Inc. (San Diego, CA, USA).

\section{Isolation of the $\mathrm{hAT}_{1}$ receptor genomic clone and the construction of the expression vectors}

To isolate the 5 '-regulatory region of the hAT ${ }_{1}$ receptor a human placental genomic library (Clontech, Palo Alto, CA, USA) was screened using an end-labeled oligonucleotide (5'-GACCCCAGG CAGCAGCGAGTGACAGG-3') that corresponds to the $5^{\prime}$-end of the published $\mathrm{hAT}_{1}$ cDNA (Bergsma et al. 1992). Nine positive clones were isolated. Southern blot analysis, using the oligonucleotide corresponding to the $5^{\prime}$-end of the hAT receptor hybridized specifically to seven clones confirming their identity as $\mathrm{hAT}_{1}$ receptor gene coding for the 5 '-sequence. Using one of these clones, HARG9, as a template for PCR and oligonucleotides from a published sequence of the promoter region (Guo et al. 1994), fragments of varying length were amplified. The oligonucleotide corresponding to exon $1(+49 \mathrm{bp}$ to $+70 \mathrm{bp})$ of the hAT $_{1}$ receptor $\left(5^{\prime}\right.$-CCGCCGCGGCCCGGCAGA GCTG-3') was used as the antisense primer for each reaction. The varying sense primers (hp1: 5'-GAGGAAGTTCCTATTCCTAG-3'; hp2: 5'CCTCACTTGACCATGGTGTATAGTC-3'; hp3: 5'-GAACACGAATCTCCGCAG-3'; hp4: 5'-GCA GCAACGCCCCTCACT-3') yielded fragments of $1348,845,384$ and $141 \mathrm{bp}$ in size respectively. Each fragment was sub-cloned into the EcoRV site of pBluescript II KS (Stratagene, La Jolla, CA, USA). These clones were then digested with SalI and XbaI to release the fragments that were consequently 
inserted into the pCAT-Basic plasmid. Removal of the GAGA box ( $-161 \mathrm{bp}$ to $-149 \mathrm{bp}$; 5'-GAGA GGGAGGAG-3') and TATA box ( $-54 \mathrm{bp}$ to $-49 \mathrm{bp}$; TATAA) was achieved by PCR amplifying the flanking regions of the respective sites separately (Thomas et al. 1995). The resultant DNA fragments were ligated and then inserted into pCAT-Basic to generate pCAThp3-GA and pCAThp3-TA respectively. The authenticity of clones was confirmed by restriction analysis and dideoxy sequencing as described previously (Thomas et al. 1995).

\section{Cell culture and transfection of reporter gene constructs}

LRCC8 cells were maintained in DMEM/F12 media supplemented with $5 \% \mathrm{FCS}, 50 \mathrm{IU} / \mathrm{ml}$ penicillin and $50 \mu \mathrm{g} / \mathrm{ml}$ streptomycin (complete medium). Transfection experiments involved growing cells to 70$80 \%$ confluence in six-well plates in complete medium. Four micrograms DNA ( $2 \mu \mathrm{g}$ reporter constructs, $2 \mu \mathrm{g}$ pSV- $\beta$-galactosidase expression construct) were transiently transfected into cells using the lipofectamine Plus reagent method as described by the manufacturer (Thomas et al. 1995). Cells were then grown for $24 \mathrm{~h}$ in complete medium.

\section{Chloramphenicol acetyl transferase (CAT) assay}

The CAT assays were performed as described previously with minor modifications (Bhat et al. 1995). Briefly, 24 h serum-depleted transfected cells were treated with and without hGH. After $18 \mathrm{~h}$ the cells were washed three times with PBS at $4{ }^{\circ} \mathrm{C}$ and collected by scraping. Cells were then centrifuged and the resultant pellet was resuspended in $70 \mu \mathrm{l}$ $0 \cdot 25 \mathrm{M}$ Tris- $\mathrm{HCl}, \mathrm{pH} \mathrm{7.8.} \mathrm{Extracts} \mathrm{were} \mathrm{prepared}$ by sonication $\left(10 \mathrm{~s}\right.$ at $\left.4{ }^{\circ} \mathrm{C}\right)$, and sedimented by centrifugation $\left(17530 \mathrm{~g}\right.$ for $5 \mathrm{~min}$ at $4{ }^{\circ} \mathrm{C}$ ). Thirty microliters of the supernatant were removed to determine $\beta$-galactosidase activity. The remaining supernatant was incubated at $70{ }^{\circ} \mathrm{C}$ for $10 \mathrm{~min}$ to inactivate endogenous acetylases and centrifuged. The CAT assay involved the addition of $20 \mu \mathrm{l}$ cellular extract to $130 \mu \mathrm{l} \mathrm{CAT}$ assay buffer $(140 \mathrm{mM}$ Tris- $\mathrm{HCl}, \mathrm{pH} 8 \cdot 0,0 \cdot 2 \mu \mathrm{Ci}\left[{ }^{14} \mathrm{C}\right]$ chloramphenicol, $4 \mathrm{mM}$ acetyl-coenzyme $\mathrm{A}$ ). The reaction mixture was incubated at $37^{\circ} \mathrm{C}$ for $1 \mathrm{~h}$ and extracted with ethyl acetate. The organic phase was removed and vacuum dried. The resultant pellet was resuspended in $30 \mu \mathrm{l}$ ethyl acetate and the labeled chloramphenicol and acetylated derivatives were separated by ascending thin-layer chromatography. The radioactivity was visualized by autoradiography and its intensity of density (IOD) quantitated by image analysis. CAT activity (IOD) was normalized with respect to levels of $\beta$-galactosidase activity, which were measured according to a previously published method (Sambrook et al. 1989).

\section{Preparation of cytosolic and nuclear extracts}

Cells were grown (100 mm plate) to $80-90 \%$ confluence in complete medium. Forty-eight hour serum-depleted cells were treated with or without hGH $(100 \mathrm{ng} / \mathrm{ml})$, epidermal growth factor (EGF) $(200 \mathrm{ng} / \mathrm{ml})$, platelet-derived growth factor (PDGF) $(100 \mathrm{ng} / \mathrm{ml})$ or insulin $(30 \mathrm{ng} / \mathrm{ml})$ for indicated times. Alternatively, cells were treated prior to hGH treatment with cyclohexamide $(1 \mu \mathrm{g} / \mathrm{ml})$ for $15 \mathrm{~min}$. The cells were washed (PBS, $4{ }^{\circ} \mathrm{C}$ ) and scraped into the same buffer. Nuclear and cytosolic extracts were made as previously described (Bhat et al. 1994). Briefly, harvested cells were resuspended in $1 \mathrm{ml}$ hypotonic solution $(10 \mathrm{mM}$ Hepes, $\mathrm{pH} 7 \cdot 9,10 \mathrm{mM}$ $\mathrm{KCl}, \quad 1.5 \mathrm{mM} \quad \mathrm{MgCl}_{2}, \quad 0.5 \mathrm{mM}$ dithiothreitol (DTT)) supplemented with protease inhibitors (0.5 mM phenylmethylsulfonyl fluoride (PMSF), $10 \mu \mathrm{g} / \mathrm{ml}$ leupeptin and $10 \mu \mathrm{g} / \mathrm{ml}$ aprotinin), Dounce homogenized and sedimented by centrifugation $(1000 \mathrm{~g}$ for $10 \mathrm{~min})$. The cytoplasmic extract (supernatant) was placed at $-70{ }^{\circ} \mathrm{C}$ for use later. The nuclei (pellet) were resuspended in a high-salt buffer $(20 \mathrm{mM}$ Hepes pH 7.9, 25\% glycerol, $400 \mathrm{mM} \mathrm{NaCl}, 1 \mathrm{mM}$ EDTA) supplemented with protease inhibitors (see above), dialyzed (membrane molecular weight cut off of $8 \mathrm{kDa}$ ) overnight in a buffer containing $20 \mathrm{mM}$ Tris- $\mathrm{HCl} \mathrm{pH} 7 \cdot 9,0 \cdot 1 \mathrm{M}$ $\mathrm{KCl}, 0 \cdot 2 \mathrm{mM}$ EDTA, $0.5 \mathrm{mM}$ DTT, $20 \%$ glycerol and $50 \mu \mathrm{g} / \mathrm{ml}$ PMSF and stored at $-70{ }^{\circ} \mathrm{C}$ for later use. Protein concentration was determined for each extract according to Bradford (1976).

\section{Electrophoretic mobility shift assay}

Gel mobility shift assays were performed as previously described (Bhat et al. 1994). pCAThp3 fragments with $5^{\prime}$-overhangs were generated by restriction enzyme (SalI/EcoRI) digestion and isolated by gel purification. In addition, a doublestranded GAGA box-containing sequence with a 5 '-overhang was generated by annealing two oligonucleotides (sense primer; 5'-GAGAGGG AGGAG-3', antisense primer; 5'-CTCCTCC CTC- $3^{\prime}$ ). The double-stranded GAGA box was labeled by filling the overhang with Klenow in the presence of $\left[\alpha^{32} \mathrm{P}\right] \mathrm{d}$ TTP and $\left[\alpha^{32} \mathrm{P}\right] \mathrm{dCTP}$. Nuclear extracts from hGH-treated and untreated cells were incubated with $1 \mu \mathrm{g}$ poly $(\mathrm{dI}-\mathrm{dC})$ at room temperature for $20 \mathrm{~min}$ in a total volume of $20 \mu \mathrm{l}$ containing 
$100 \mathrm{mM}$ Tris- $\mathrm{HCl}, \mathrm{pH} 8 \cdot 0,50 \%$ glycerol, $500 \mathrm{mM}$ $\mathrm{KCl}, 10 \mathrm{mM}$ EDTA, and $10 \mathrm{mM}$ DTT supplemented with either $2 \mu \mathrm{l}$ proteinase $\mathrm{K}$, varying concentrations ( 0 to 50 times) of unlabeled doublestranded GAGA box, 50-fold excess of unlabeled double-stranded mutant GAGA (Mut1: 5'-GAG ATTTAGGAG-3'; Mut2: 5'-AAAAGGGAG GAG-3'; Mut3: 5'-GAGAGGGAAAAA-3'; Mut4: 5'-AAAATTTAGGAG-3') or water. Labeled probe (200 000 c.p.m.) was then added and the incubation continued for a further $10 \mathrm{~min}$. The DNA-protein complex was electrophoresed on a $4 \%$ native polyacrylamide gel containing $0.5 \times$ Tris-borate EDTA buffer $(25 \mathrm{mM}$ Tris-HCl, $25 \mathrm{mM}$ boric acid, $0.5 \mathrm{mM}$ EDTA). Gels were run at $240 \mathrm{~V}$ at $4{ }^{\circ} \mathrm{C}$, dried and exposed to Fuji RX-film at $-70{ }^{\circ} \mathrm{C}$.

\section{Southwestern analysis}

Nuclear and cytosolic extracts were fractionated through a $12 \%$ SDS-polyacrylamide gel and electrophoretically transferred to nitrocellulose membranes as described previously (Bhat et al. 1994). Membranes were then washed in PBS, prehybridized in a buffer containing $10 \mathrm{mM}$ Tris- $\mathrm{HCl}(\mathrm{pH} \quad 8 \cdot 0), 5 \%$ glycerol, $50 \mathrm{mM} \mathrm{KCl}$, $1 \mathrm{mM}$ EDTA, $1 \mathrm{mM}$ DTT, $0.5 \mathrm{mM}$ PMSF and $500 \mathrm{ng} / \mathrm{ml}$ salmon sperm for $30 \mathrm{~min}$ and then incubated with ${ }^{32} \mathrm{P}$-labeled double-stranded GAGA box or pCAThp3 for $30 \mathrm{~min}$. To remove nonspecific DNA binding, DNase I was added (2 units, $15 \mathrm{~min})$ at $37^{\circ} \mathrm{C}$. The membranes were washed (PBS, $22^{\circ} \mathrm{C}$ ) twice and exposed to $\mathrm{X}$-ray film at $-70{ }^{\circ} \mathrm{C}$ with intensifying screens.

\section{Computer analysis and statistical methods}

Sequence analyses and alignment were performed using MacVector 6.5 sequence analysis software. Transcription factors search and analysis were performed using TESS (Transcription Element Search Software) on the World Wide Web (URL: http://www.cbil.upenn.edu/tess/index.html). Statistical differences between two experimental groups were tested by Student's $t$-test for unpaired samples using the computer software GraphPad Prism.

\section{RESULTS}

\section{Cloning of the $\mathrm{hAT}_{1}$ gene promoter and its introduction to reporter gene constructs}

The authenticity of our isolated genomic clone, HARG9, was confirmed by sequence analysis using primers corresponding to the published $\mathrm{hAT}_{1}$ promoter. Computer analysis of the $\mathrm{hAT}_{1}$ promoter region indicated putative binding sites including TATA, specificity protein $1(\mathrm{Sp} 1)$ and numerous activator protein 1 (AP1) within the first $1000 \mathrm{bp}$ upstream of the transcription start site (Guo et al. 1994). In this study, we investigated the involvement of the $-1278 \mathrm{bp}$ to $+70 \mathrm{bp}$ fragment in the regulation of the hAT1 gene. To define the role of specific DNA sequences within this region, various sized deletion constructs were created and placed upstream of the CAT reporter gene expression vector (Fig. 1).

\section{Measurement of $\mathrm{hAT}_{1}$ transcription}

Reporter pCAT constructs were transiently transfected into LRCC8 cells and treated with or without hGH $(100 \mathrm{ng} / \mathrm{ml})$. GH significantly increased CAT activity in cells expressing pCAThp1 (382 \pm 156 IOD (s.E.M); $P<0.05)$, pCAThp2 $(427 \pm 140$ IOD; $P<0.05)$ and pCAThp3 (520 \pm 230 IOD; $P<0.05)$ above their relative basal levels (pCAThp1: $61 \pm 25$ IOD; pCAThp2: $41 \pm 28$ IOD; pCAThp3: $95 \pm 48$ IOD) (Fig. 2). CAT activity of cells expressing pCAThp4 was unchanged with hGH treatment $(4 \pm 1)$ compared with basal levels $(9 \pm 7)$. These results suggest that the DNA sequence required for $\mathrm{hGH}$-induced transcription of the $\mathrm{hAT}_{1}$ is located between -314 bp (pCAThp3) and -71 bp (pCAThp4). hGH produced a dose-dependent increase of CAT activity in cells transfected with pCAThp3 (Fig. 3). Maximal response was observed at an hGH dose of $100 \mathrm{ng} / \mathrm{ml} \quad(5 \cdot 3 \pm 2 \cdot 1$-fold increase over basal), which was maintained at $200 \mathrm{ng} / \mathrm{ml}(5 \cdot 4 \pm 2 \cdot 3$-fold increase over basal).

\section{Identification of hGH-induced cis-acting element on the hAT1 gene}

Computer analysis indicated a number of putative binding sites located in the region between primers hp 3 and hp4 (Fig. 1). A 12 bp sequence (5'-GAG AGGGAGGAG-3') found within $-161 \mathrm{bp}$ to $-149 \mathrm{bp}$ of the $\mathrm{hAT}_{1}$ gene showed $92 \%$ homology with a GH regulatory element (GAGA box) located on the rat serine protease inhibitor $2 \cdot 1$ (rSpi2.1) gene (Le Cam et al. 1994). Thus, we refer to this sequence as the $\mathrm{hAT}_{1}$-GAGA box. To confirm the

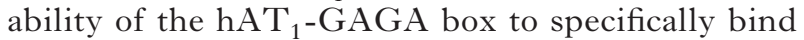
hGH-induced nuclear protein(s), a mobility shift assay was performed using proximal tubule cell nuclear extracts and labeled $\mathrm{hAT}_{1}$-GAGA as the probe. Nuclear extracts from cells treated with hGH showed a mobility shift of the labeled GAGA box (Fig. 4A, lane 2). There was no specific binding of the labeled $\mathrm{hAT}_{1}$-GAGA probe in nuclear 

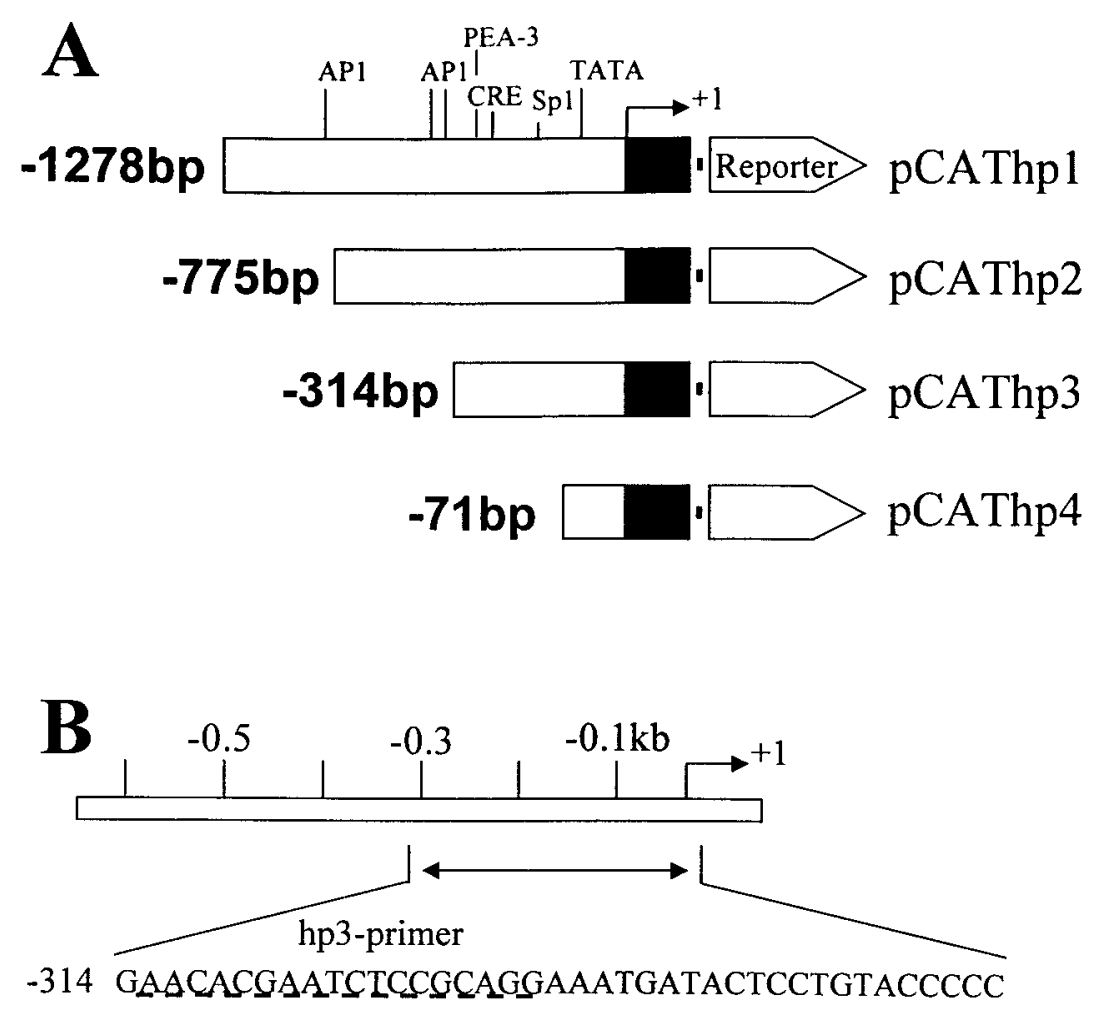

-274 AGCTCGCTCTCCCTCACGACCCCTCGCTAGGCGGGGTTCG

-234 GGACCAGGTGAACGCTGATCTGATAGTTGACACGGGACGA

GAGA Box

$\mathrm{Spl}$

-154 AGGAGGTTGGGCCGGGAGGGTCTCCGGGGCGGGGCGGAGG

-114 AGGAGGGAATGCAAAACAGAGCCTCGTCCCCGGAACCCAA hp4-primer TATA Box

-74 GAAGCAGCAACGCCCITCACTATAAATTCGGAGCTGCCTC

-34 CTCGCCAATGATTCCAGCGCCTGACAGCCAGGACC $\stackrel{{ }^{-}+1}{\longrightarrow}$

FIGURE 1. The 5 '-regulatory region of the hAT ${ }_{1}$ gene. (A) A schematic representation of the pCAT reporter expression vector containing serially deleted $5^{\prime}$-promoter region of the hAT $_{1}$ gene. pCAThp1 is labeled with a number of computer-generated putative transcription binding sites. (B) DNA sequence of the $314 \mathrm{bp}$ fragment of the $\mathrm{hAT}_{1}$ promoter. Primer sequences used in the construction of DNA fragments pCAThp3 and pCAThp4 are shown by a dotted line. The TATA, GAGA and Sp1 sites are boxed. +1 refers to the 5 -end of the cDNA clone obtained by Bergsma et al. (1992). The arrow indicates the transcription start site shown in Curnow et al. (1995).

extracts from untreated cells under these conditions (lane 4). Pre-treatment with proteinase $\mathrm{K}$ abolished the mobility shift of the $\mathrm{hAT}_{1}$-GAGA probe (lane 3 ) indicating the formation of an hGH-induced protein-DNA complex. The presence of increasing concentrations (0-50 times) of unlabeled $\mathrm{hAT}_{1}$ GAGA probe progressively abolished the proteinDNA complex formation, demonstrating the specificity of the protein binding to the $\mathrm{hAT}_{1}$ GAGA box (Fig. 4B). To identify the essential 


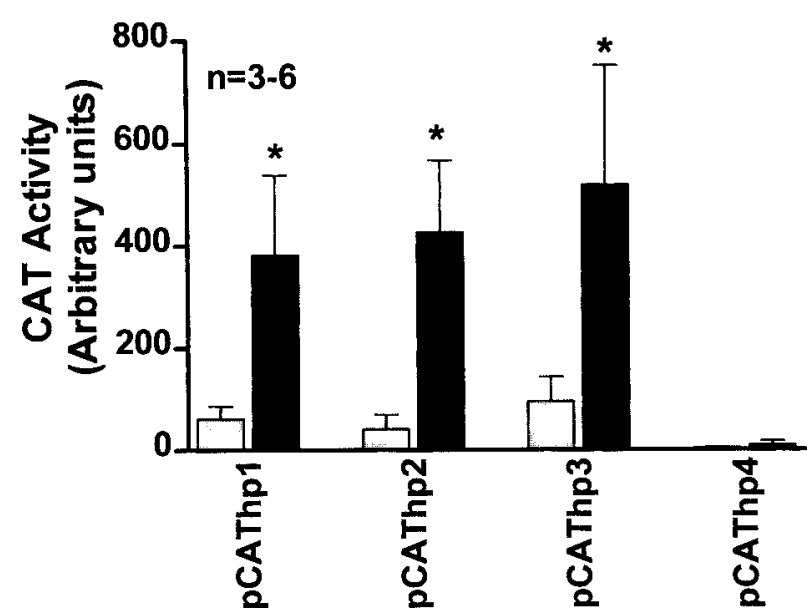

FIGURE 2. Human GH-induced CAT activity of hAT reporter gene constructs. CAT activity for the serially deleted promoter fragments in pCAT vector was determined. Bars represent the CAT activity for each serially deleted promoter fragment in cells treated with (closed bars) or without (shaded bars) hGH $(100 \mathrm{ng} / \mathrm{ml}$ ) for $18 \mathrm{~h}$. ' $\mathrm{n}$ ' represents the number of experiments. Values are the mean \pm s.E.M. $* P<0 \cdot 05$.

DNA sequences within the GAGA motif necessary for nuclear factor(s) to bind GAGA-DNA, mobility shift assays were performed with GH-treated nuclear extracts in the presence of 50-fold excess of unlabeled mutant GAGA-DNA. Figure 5

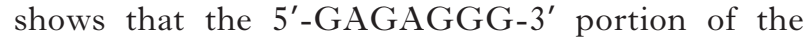
hAT1-GAGA is required for protein(s) to bind,

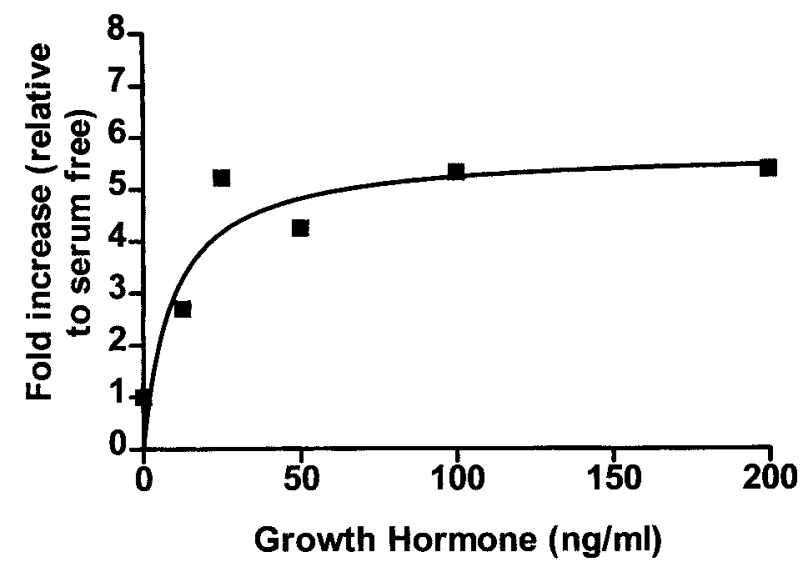

FIGURE 3. Dose-response of hGH to CAT activity of pCAThp3. LRCC8 cells were transfected with pCAThp3, treated with hGH $(0-200 \mathrm{ng} / \mathrm{ml})$ and CAT activity measured. hGH-induced activity is expressed as a fold increase relative to the activity of untreated cells. Data shown are representative of multiple experiments $(n=4)$.

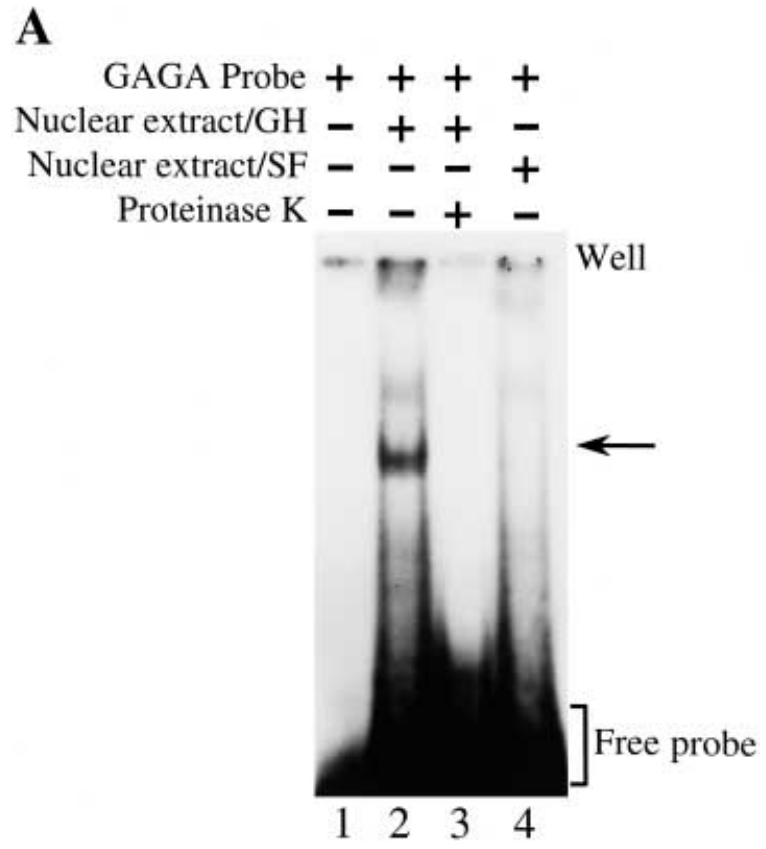

B

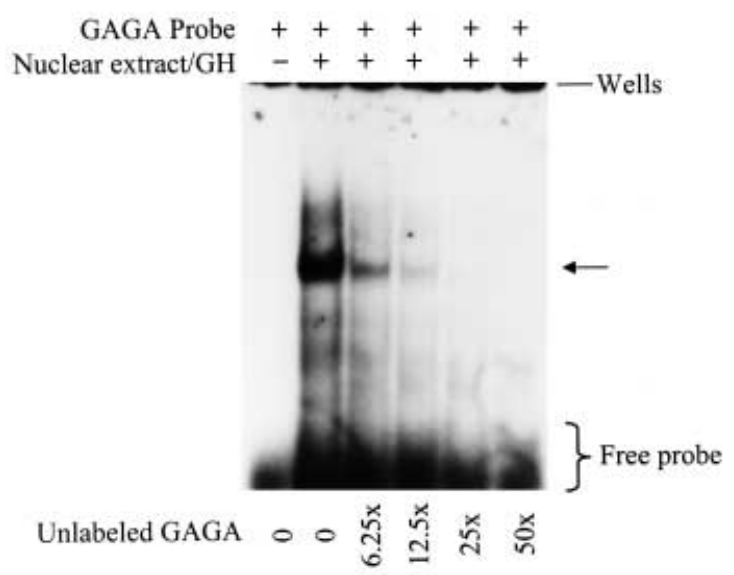

FIGURE 4. Identification of specific protein binding activity, in nuclear extracts from LRCC8 cells, to the GAGA box of the hAT $_{1}$ promoter. The mobility shift assay was performed as described in Materials and Methods. ${ }^{32}$ P-labeled GAGA probe was incubated with nuclear extracts $(10 \mu \mathrm{g})$ from LRCC8 cells. Samples were analyzed after electrophoresis on a $4 \%$ non-denaturing polyacrylamide gel and autoradiography. (A) Labeled probe in the absence of extract (lane 1), in the presence of $\mathrm{hGH}(100 \mathrm{ng} / \mathrm{ml})$-treated extract (lane 2$)$, in the presence of GH-treated extract with proteinase $\mathrm{K}$ (lane 3), and in the presence of hGH-untreated extract (lane 4). (B) A mobility shift assay was performed using the labeled GAGA probe in the presence of hGH-treated nuclear extracts and increasing concentrations of unlabeled GAGA probe, as indicated. The arrow indicates the position of the protein-DNA complex. 


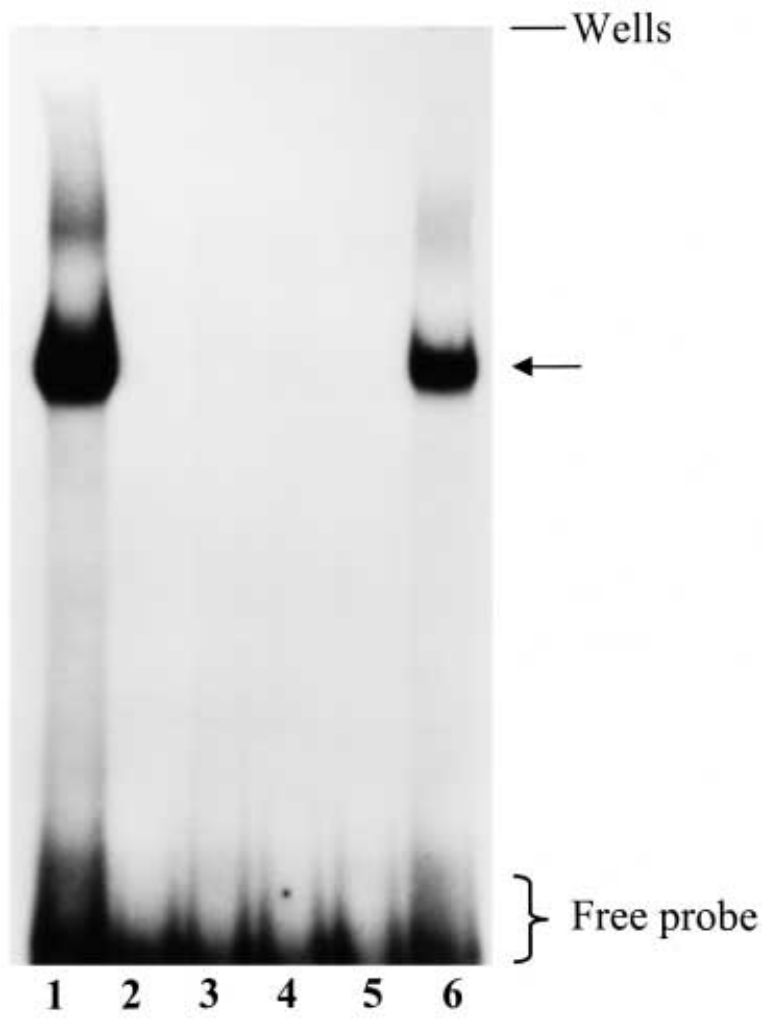

FIGURE 5. Determination of specific DNA sequences within the GAGA necessary for nuclear factor to bind GAGA-DNA. The mobility shift assay was performed with hGH-treated nuclear extracts in the presence of unlabeled double-stranded mutant GAGA-DNA. Samples were analyzed after electrophoresis on a $4 \%$ non-denaturing polyacrylamide gel and autoradiography. Lane 1, nuclear extract $(10 \mu \mathrm{g})$ incubated with

${ }^{32} \mathrm{P}$-labeled double-stranded GAGA probe $\left(5^{\prime}\right.$-GAGAG GGAGGAG-3'); lane 2, nuclear extract incubated with

${ }^{32}$ P-labeled GAGA to which 50 -fold excess of unlabeled GAGA was added as a competitor; lanes 3-6, nuclear extract incubated with ${ }^{32} \mathrm{P}$-labeled GAGA to which 50 -fold excess of unlabeled double-stranded mutant GAGA (lane 3; 5'-GAGATTTAGGAG-3', lane 4; 5'-AAAAGGGAGGAG-3', lane 5; 5'-GAGA GGGAAAAA-3', lane 6; 5'-AAAAT'TTAGGAG-3') was added as competitor. Underlined sequences indicate the mutated bases. The arrow indicates the position of the protein-GAGA-DNA complex.

although certain mutations within the $5^{\prime}$-end or $3^{\prime}$-end of this sequence have no effect and allow effective competition with the wild-type sequence.

\section{Identification of trans-acting factor}

To determine the direct interaction between the GAGA box and the nuclear protein(s), Southwestern analysis was performed. Figure 6 indicates

www.endocrinology.org

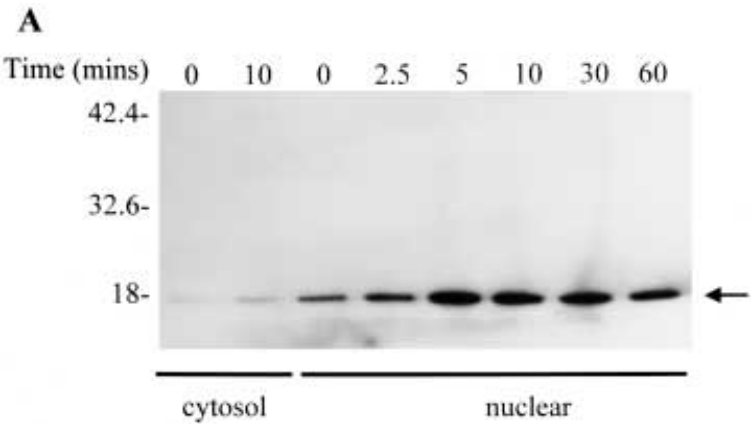

B

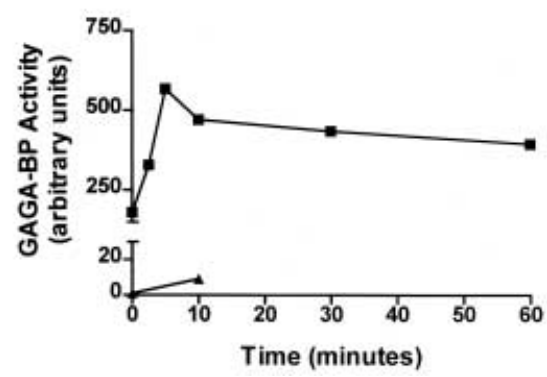

FIGURE 6. Demonstration of direct binding of an $18 \mathrm{kDa}$ protein to the GAGA sequence of the $\mathrm{hAT}_{1}$ gene. Southwestern analysis was performed to identify the direct interaction between the GAGA sequence and its binding protein. Cytosolic $(10 \mu \mathrm{g})$ and nuclear $(10 \mu \mathrm{g})$ extracts from LRCC8 cells were separated on $12 \%$ SDS-PAGE, transferred to a nitrocellulose membrane and hybridized with ${ }^{32} \mathrm{P}$-labeled GAGA probe. (A) The time course of hGH $(100 \mathrm{ng} / \mathrm{ml})$ activation of an $18 \mathrm{kDa}$ protein (cytosolic and nuclear, as indicated). The arrow indicates the position of the GAGA-BP. (B) Densitometeric analysis of the blot, plotted for the hGH-induced activation over time ( $\square$ nuclear, $\boldsymbol{\Delta}$ cytosolic). This is an autoradiograph representative of four experiments.

that an $18 \mathrm{kDa}$ DNA-binding protein interacts directly with the hAT ${ }_{1}$-GAGA box. The pCAThp3 DNA fragment also recognized the $18 \mathrm{kDa}$ binding protein with the same specificity as the GAGA probe (data not shown). This GAGA box-binding protein (GAGA-BP) was principally present in the nuclear fraction. Treatment of cells with hGH for varying times indicated that the $18 \mathrm{kDa}$ protein was activated within 2.5 min reaching a maximum at $5 \mathrm{~min}$. The observed activity of this protein was maintained up to $60 \mathrm{~min}$ after hGH treatment. Addition of excess unlabeled GAGA-DNA successfully competed with the binding of the GAGA probe to the $18 \mathrm{kDa}$ protein (data not shown). The immediate activation, as early as $2.5 \mathrm{~min}$, of the 


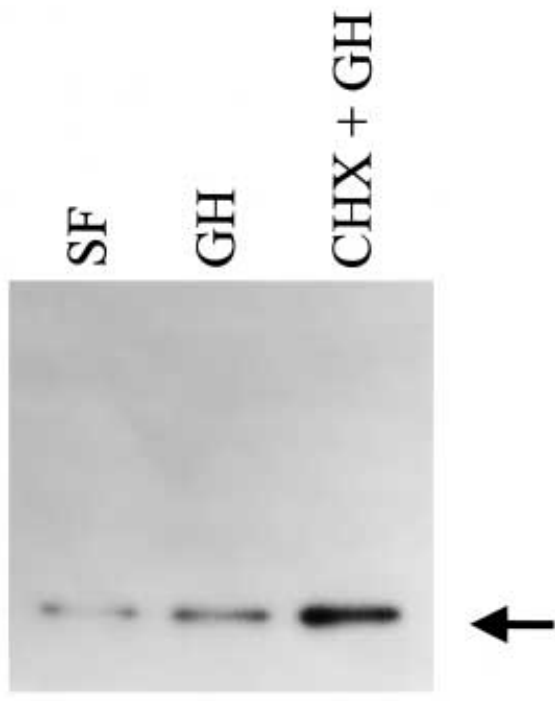

FIGURE 7. Determination of whether GAGA-BP activation requires de novo protein synthesis. Nuclear extracts $(10 \mu \mathrm{g})$ from LRCC8 cells that were untreated (SF), treated with $100 \mathrm{ng} / \mathrm{ml} \mathrm{hGH}(\mathrm{GH})$ for $5 \mathrm{~min}$ or treated with cyclohexamide $(1 \mu \mathrm{g} / \mathrm{ml})$ and $\mathrm{hGH}$ $(\mathrm{CHX}+\mathrm{GH})$ underwent Southwestern analysis using the ${ }^{32} \mathrm{P}$-labeled double-stranded GAGA probe. Data shown are representative of multiple experiments $(n=4)$. The arrow indicates the position of GAGA-BP.

$18 \mathrm{kDa}$ protein by $\mathrm{hGH}$ suggests that de novo synthesis is not required for its activation. To confirm this, cells were pre-treated with a protein synthesis inhibitor cyclohexamide $(1 \mu \mathrm{g} / \mathrm{ml})$ and hGH-induced activity was measured (Fig. 7). Our results show that inhibition of protein synthesis did not reduce hGH-induced activity of the $18 \mathrm{kDa}$ protein to bind the $\mathrm{hAT}_{1}$-GAGA box.

\section{Functional analysis of the $\mathrm{hAT}_{1}$-GAGA box}

To determine whether the GAGA box was responsible for $\mathrm{hGH}$-induced transcription of the $\mathrm{hAT}_{1}$ receptor, we constructed a pCAThp3 mutant in which the GAGA box (pCAThp3-GA) was selectively removed. When pCAThp3-GA was transfected into LRCC8 both hGH-induced transcription and basal transcription were inhibited (Fig. 8). To further investigate basal transcription of the $\mathrm{hAT}_{1}$ gene, the putative TATA sequence was selectively deleted from pCAThp3. This deletion (pCAThp3TA) did not abolish basal transcription and had no effect on hGH-induced transcription. These results indicate that the GAGA box and not the putative TATA sequence is responsible for the hGH-induced as well as basal transcription of the $\mathrm{hAT}_{1}$ gene.

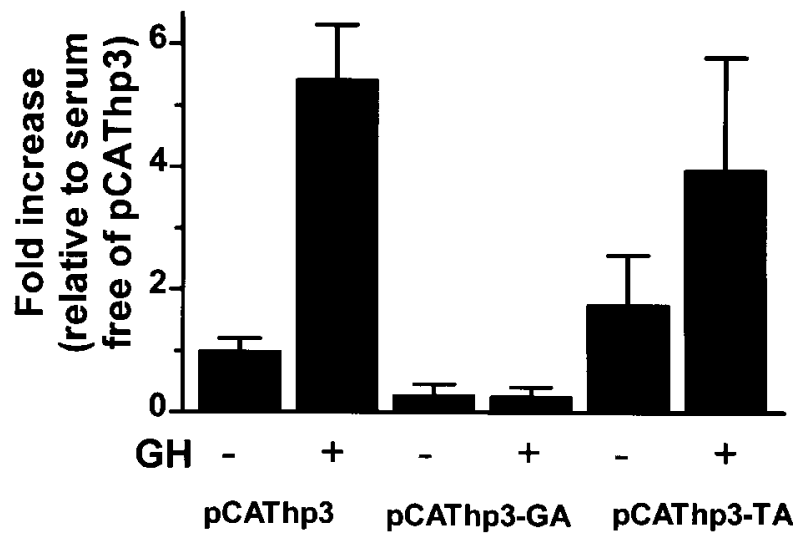

FIGURE 8. CAT activity of LRCC8 cells expressing pCAThp 3 mutants. pCAThp3-GA and pCAThp3-TA mutants were constructed, transfected and treated with and without hGH $(100 \mathrm{ng} / \mathrm{ml})$. Bars represent CAT activity for each fragment relative to the activity of untreated cells expressing the pCAThp3 fragment. Data shown are means \pm S.E.M. of four separate experiments.

\section{hAT $_{1}$-GAGA box is a cis-acting element for other growth factors}

To determine if growth factors which have similar signaling pathways to hGH can activate the GAGA-BP, cells were treated for 5 min with either EGF $(200 \mathrm{ng} / \mathrm{ml})$, PDGF $(100 \mathrm{ng} / \mathrm{ml})$ or insulin $(30 \mathrm{ng} / \mathrm{ml})$. Southwestern analysis indicated that nuclear extracts from PDGF-, EGF- and insulintreated cells increased the binding activity of the GAGA-BP (Fig. 9). This result indicates that the GAGA box may function as a common cis-acting element for growth factor(s)-induced trans-acting factor (GAGA-BP) in $\mathrm{hAT}_{1}$ gene transcription.

\section{DISCUSSION}

The transcription of $\mathrm{hAT}_{1}$ receptors is a complex process, as indicated by differences in tissue-specific expression and developmental regulation. The recent cloning and identification of the $5^{\prime}$-regulatory region of $\mathrm{hAT}_{1}$ enabled us to investigate regulation of $\mathrm{hAT}_{1}$ transcription. In this study, we have identified a novel regulatory element of the hAT gene that is between $-161 \mathrm{bp}$ and $-149 \mathrm{bp}$ (hAT ${ }_{1}$-GAGA box) upstream of the 5 '-end of the cDNA sequence identified by Bergsma et al. (1992). This element is involved in growth factor(s)mediated as well as basal transcription of the $\mathrm{hAT}_{1}$ receptor gene. Yet the lack of endogenous $\mathrm{hAT}_{1}$ receptor mRNA and protein expression in immortalized cell lines, including the one we used in this study, makes it difficult to address the correlation 


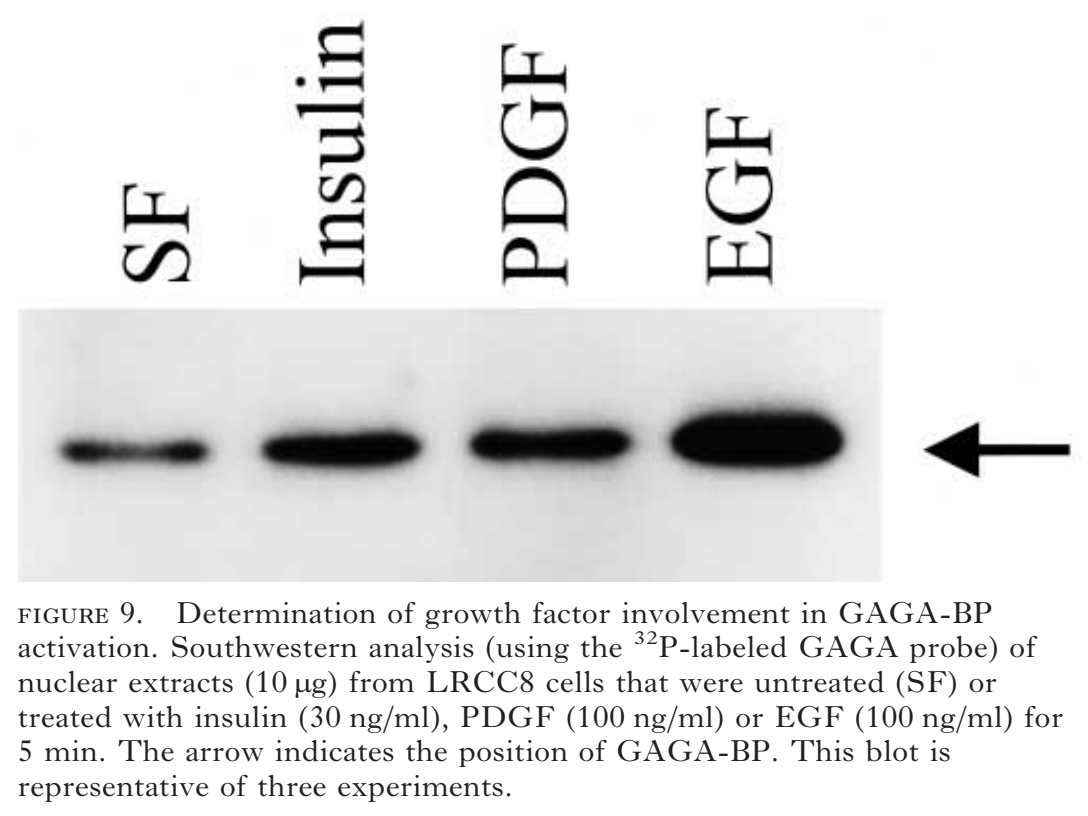

between the GH and the endogenous $\mathrm{hAT}_{1}$. However, we have previously shown in rat studies that a deficiency in GH is associated with a decrease in $\mathrm{AT}_{1 \mathrm{~A}}$ receptor (in all organs measured) and infusion of $\mathrm{GH}$ increased $\mathrm{AT}_{1 \mathrm{~A}}$ receptors towards normal (Wyse et al. 1993). In addition, we have shown in primary astrocytes culture cells that GH selectively upregulates the endogenous $\mathrm{AT}_{1 \mathrm{~A}}$ receptor mRNA at the transcriptional level (Wyse \& Sernia 1997). Computer analysis of the rat $\mathrm{AT}_{1}$ receptor's 5'-regulatory region indicates that the $\mathrm{AT}_{1 \mathrm{~A}}$ and not the $\mathrm{AT}_{1 \mathrm{~B}}$ possesses a similar GAGA box to that found in the $\mathrm{hAT}_{1}$ receptor (Fig. 10). This observation suggests GH-mediated transcriptional regulation of rat $\mathrm{AT}_{1 \mathrm{~A}}$ and $\mathrm{hAT}_{1}$ receptors may utilize similar mechanisms. Functional GAGA boxes have been identified in the promoter regions of a number of genes in different species including the Drosophila Kruppel (Kerrigan et al. 1991) and heat shock proteins (Lee et al. 1992, Lu et al. 1993), rSpi2.1 (Le Cam et al. 1994), human $\alpha 1(\mathrm{~V})$ collagen (Lee \& Greenspan 1995) and murine p44 mitogenactivated protein kinase (Pages et al. 1995). These GAGA boxes possess GA repeats; however, the overall sequence differs between the genes and species suggesting gene- and species-specific regulation. The closest sequence homology to the $\mathrm{hAT}_{1}$-GAGA is the rSpi2.1-GAGA box (Le Cam et al. 1994) that shows a $92 \%$ homology. The rSpi2-1-GAGA box contains two GAGGAG repeats separated by a $G$. The difference between the $\mathrm{hAT}_{1}$-GAGA and the rSpi2.1-GAGA is a single base $(G)$ deletion in the middle of one of the
GAGGAG repeats. Interestingly, like the $\mathrm{hAT}_{1}$ GAGA box, to our knowledge, the rSpi2-1-GAGA box is the only other GAGA box that mediates basal and growth factor-dependent gene transcription (Legraverend et al. 1996).

The interaction between TATA-binding proteins (TBP) and the TATA element is generally the first step in the initiation of RNA polymerase IIdependent transcription. In the absence of a functional TATA element, other $c i s$-acting elements are also capable of promoting transcription initiation (Bossone et al. 1992). Promoter-specific transcription by RNA polymerase II is often dictated by binding of activator proteins to upstream DNA elements. However, the mechanism by which activator proteins stimulate promoterspecific transcription remains unclear. The use of a pCAThp3 mutation (pCAThp3-GA) showed that selective removal of the $\mathrm{hAT}_{1}$-GAGA box blocked the action of $\mathrm{hGH}$ to induce $\mathrm{hAT}_{1}$ transcription. In addition, basal promoter activity was abolished suggesting that the $\mathrm{hAT}_{1}$-GAGA box acts as a bifunctional cis-acting element in that it is important in controlling both basal as well as growth factor-induced transcription of the $\mathrm{hAT}_{1}$ gene. Selective removal of the TATA did not alter the basal promoter activity or the ability of hGH to induce the $\mathrm{hAT}_{1}$ transcription. These results suggest the $\mathrm{hAT}_{1}$-GAGA box and not the TATA element is essential for basal transcription of the $\mathrm{hAT}_{1}$ gene. However, two studies indicate that the $\mathrm{hAT}_{1}$ TATA box is functional based on the observation that initiation starts downstream of the 
-314 GAACACGAACTCCCGCAGGAAATGATACT-CCTGTACCCCCAGCTCGCTC-TCCCT hAT1

-290 GAGCATTTATCTTGGAGTCAGTTCATGTGGCCT-TATGCCCACCTCCCTCCATCTT rAT1A

-324 AAACAAGAGAACAAAAGAAAAAAAGAGGAGTATTTCTCTCCAAAGTAAATAACATT rAT1B

-260 CACGACCCCTCGCTAGGC-G-GGGT-TCGGGACCAGGTGAACGCTGATCTGATAGT

-235 CAACACTTCAAGCTGGGATGAGGGAGTCAGGACCAGCTGAGCTTGGATCTGGAAGG

-268 GCTTGACCCCACACAGATCCCTCCCTCTTCAAGACCCTCTCTAAGAGATGCAGCAT

-207 TGACACGGGACGACTGTGGCATCATCCTTGCTGCCGTCAATATCCCGAGAGGGAGG

-179 CGACACTGGGTGACT--GGCAGCAGGGAAGGCGCCGTCAGAAACTAGAGAGGGAGC

-212 TCCAGGCCCAAGTGAGCCTGTATCAGGTAGGTGACACTGGAGTACATTGGAGTCAT Sp1 site

-151 AGGTTGGCCGGGAGGTCTCCGGGGCGGGCGGAGGAGGAGGGAATGCAAAACAG

-125 GGGITGGACAG--AGGGTCTC-AGGGCGGGGCGGGGGAGGAG- - - TGCAAAGCCG

-156 GCTTGCCTTAGTAAGAATCTGTCAAGGGAGGGGTCAGGAGGGTCTTTTAGGCGGAG TATA Box

-95 AGCCTCGTCCCCGGAACCCAAGAAGCAGCAACGC-CCCT--CACTATAAATTCGGA

-76 AGCCTGAGGGTTGGAACCTGCAGAGCAGCGACGCCCCCTAG-GCTATAAATATGGA -100 CGACCAGGGAAGGCAAACCCAGCTT-AGCAACGCCCCTTTGCTGAATAAATTGGAG

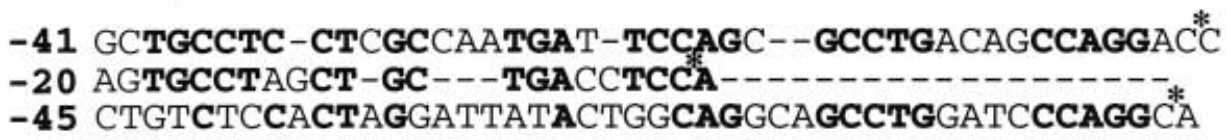

FIGURE 10. Promoter sequence alignment of the human and rat $\mathrm{AT}_{1}$ receptors. Comparison of the putative regulatory region of the $\mathrm{hAT}_{1}$ (top line), the rat $\mathrm{AT}_{1 \mathrm{~A}}$ (middle line) and the rat $\mathrm{AT}_{1 \mathrm{~B}}$ (bottom line). The shaded box highlights the GAGA motif and the open boxes highlight the Sp1 and TATA motifs. Their relative locations with respect to the putative transcription start site of each gene are indicated with an asterisk (Guo \& Inagami 1994 , Guo et al. 1994, Takeuchi et al. 1993). Sequences common to $\mathrm{hAT}_{1}$ and rat $\mathrm{AT}_{1 \mathrm{~A}}$ or $\mathrm{hAT}_{1}$ and rat $\mathrm{AT}_{1 \mathrm{~B}}$ are indicated in bold.

TATA motif ( $\mathrm{Su}$ et al. 1994, Takayanagi et al. 1994). In contrast, a more recent study suggests that the transcription initiation site is located on the last A residue of the putative TATA element (Curnow et al. 1995). If this later observation is correct, it would be necessary for the activator proteins or TBP to bind upstream of the TATA motif in order for RNA polymerase to initiate transcription from the TATA element. Our data that the $\mathrm{hAT}_{1}$ GAGA box is necessary for basal as well as hGH-induced transcription support this contention. The $\mathrm{hAT}_{1}$-GAGA box may be used as an accessible region either for basic transcriptional machinery in the presence of a functional TATA box, or as an essential site for the transcription initiation and interaction of other activator DNAbinding proteins (in the presence of a nonfunctional TATA motif). Numerous studies have demonstrated that a GAGA box can be involved in transcription initiation with or without the presence of a functional TATA element. For example, in the hsp70 promoter of Drosophila melanogaster, the GAGA box is required for TBP recruitment to its TATA motif (Weber et al. 1997). Alternatively, a number of GAGA boxes found in TATA-less promoters of other genes have been shown to be necessary for the initiation of transcription (Bossone et al. 1992). Although it is possible that the $\mathrm{hAT}_{1}$ gene may possess alternate initiation sites that are determined by the presence or absence of GAGA-BP(s), the mechanism by which the receptor can choose the alternate sites to initiate transcription remains to be determined.

We have identified an $\mathrm{hGH} /$ growth factor(s)induced $18 \mathrm{kDa}$ protein, which acts as a transcription factor by binding to the $\mathrm{hAT}_{1}$-GAGA box of the $\mathrm{hAT}_{1}$ gene. The GAGA-BP was found in the cell cytoplasm as well as in the nucleus. Although the presence of low levels of active GAGA-BP in the cytosolic fraction may be a result of contamination with nuclear proteins (during the preparation), consistency in our observation suggests that the GAGA-BP is translocated to the nucleus before binding to the $\mathrm{hAT}_{1}$-GAGA box. Cyclohexamide, a protein synthesis inhibitor, did not reduce growth factor activation of the GAGA-BP, suggesting de novo synthesis is not required for the regulatory effects of $\mathrm{hGH} /$ growth factor(s). The observation that cyclohexamide treatment resulted in superinduction of the GAGA-BP suggests that de novo protein synthesis is involved in the stability of GAGA-BP and/or that cyclohexamide blocks a 
factor(s) which inhibits GAGA-BP activation. The mechanism by which the GAGA-BP is activated in the nucleus by $\mathrm{hGH} /$ growth factor(s) requires further investigation. There are a number of known transcription factors that are activated by GHinduced phosphorylation. These include signal transducers and activators of transcription (STAT) proteins, insulin receptor substrates 1 and 2 and c-fos and c-Jun (Ogbourne \& Antalis 1998). Our data suggest the GAGA-BP is a novel transcription factor induced by $\mathrm{hGH}$, as the observed size of GAGA-BP (18 kDa) differs from the size of known $\mathrm{hGH}$-induced transcription factors. In addition, the $\mathrm{hAT}_{1}$-GAGA box is not a known binding site for many growth factor-induced transcription factors such as STATs, nuclear factor- $\kappa \mathrm{B}$, c-fos and c-Jun. There have been a number of GAGA-BPs identified, although none has a similar size to $\mathrm{hAT}_{1}$-GAGA-BP. For instance MAZ, a human zinc finger protein, binds to the GA box of the c-MYC gene and regulates the initiation of its transcription (Bossone et al. 1992). MAZ is a $52.5 \mathrm{kDa}$ protein that is found abundantly in numerous tissues with the exception of the kidney. The hAT $_{1}$-GAGA-BP identified in this study may be related to MAZ in function but its size and tissue distribution differ from the $\mathrm{hAT}_{1}$-GAGA-BP. Our data suggest that the $\mathrm{hAT}_{1}$-GAGA-BP is both a novel hGH transcription factor as well as a novel GAGA-BP. The observation that PDGF, EGF and insulin activate GAGA-BP indicates that the $18 \mathrm{kDa}$ protein is a common transcription factor for numerous growth factors and may be activated by shared signaling pathways. This is supported by Legraverend et al. (1996) who showed that both GH and interleukin-6 increased the transcription of the rSpi2.1 through its GAGA box. While those investigators demonstrated that activation of the rSpi2-1-GAGA-BP was via a Janus kinase 2-dependent, STAT-independent pathway, they did not identity the transcription factor(s) involved. Since the rSpi $2 \cdot 1$ - and $\mathrm{hAT}_{1}$-GAGA boxes are $92 \%$ sequence homologous, we believe that the $\mathrm{hAT}_{1}$ GAGA-BP may be the same protein involved in the transcriptional regulation of both genes. It is possible that there will be additional proteins involved in the overall regulation of $\mathrm{hAT}_{1}$ gene transcription through the $\mathrm{hAT}_{1}-\mathrm{GAGA}_{\mathrm{box}}$. These would not be detected by Southwestern analysis, as the denaturing SDS-PAGE conditions would prevent interaction between these additional proteins and the $\mathrm{hAT}_{1}$-GAGA-BP. It is worth noting that a prolonged exposure of a Southwestern gel revealed other higher molecular weight proteins bound to the labeled $\mathrm{hAT}_{1}$-GAGA probe (data not shown). These were of relative low intensity

www.endocrinology.org compared with the GAGA-BP. These findings indicate that the GAGA-BP preferentially binds to the $\mathrm{hAT}_{1}$-GAGA box but other proteins may have binding affinity for DNA sequences found within the $\mathrm{hAT}_{1}$-GAGA box of the $\mathrm{hAT}_{1} 5^{\prime}$-regulatory region.

In summary, our studies show that $\mathrm{hAT}_{1}$ gene transcription can be activated by hGH as well as other growth factors. This activation is mediated by a cis-acting element that consists of a GAGA sequence located in the $5^{\prime}$-regulatory region of the gene. Furthermore, we identified an hGH/growth factor(s) activating an $18 \mathrm{kDa}$ DNA-binding transacting factor that specifically recognizes the $\mathrm{hAT}_{1}$ GAGA sequence. The formation of the complex between the hGH-induced GAGA-BP and the $\mathrm{hAT}_{1}$-GAGA box is responsible for the hGHmediated increase in $\mathrm{hAT}_{1}$ gene transcription in vitro. The existence of this relationship in vivo is difficult to address in humans; however, studies in the rat show that the GH-mediated transcription of the rat Spi2.1 gene via the rat GAGA box in vitro is transposed to an in vivo model (hypophysectomized rats) (Simar-Blanchet et al. 1998). If the hGHmediated increase in $\mathrm{hAT}_{1}$ gene transcription occurs in vivo, some of the metabolic effects of altered hGH levels in humans (sodium and fluid retention) may be explained. Isolation of the GAGA-BP will allow an understanding of the molecular mechanisms by which hGH and other growth factors influence hAT1 gene transcription.

\section{ACKNOWLEDGEMENTS}

We would like to thank Dr Walter G Thomas for his helpful comments. This work was supported in part by grants from the US National Institutes of Health (HL61356), the American Heart Association (CWGS-39-96) and the American Diabetes Association to T J T. B D W was a recipient of the Renal Division Post Doctoral Fellowship at the University of Colorado Health Sciences Center.

\section{REFERENCES}

Bergsma DJ, Ellis C, Kumar C, Nuthulaganti P, Kersten H, Elshourbagy N, Griffin E, Stadel JM \& Aiyar N 1992 Cloning and characterization of a human angiotensin II type 1 receptor. Biochemical and Biophysical Research Communications 183 989-995.

Bhat GJ, Thekkumkara TJ, Thomas WG, Conrad KM \& Baker KM 1994 Angiotensin II stimulates cis-inducing factor-like DNA binding activity. Evidence that the AT1A receptor activates transcription factor-Stat91 and/or a related protein. Fournal of Biological Chemistry 269 31443-31449. 
Bhat GJ, Thekkumkara TJ, Thomas WG, Conrad KM \& Baker KM 1995 Activation of the STAT pathway by angiotensin II in T3 CHO/AT1A cells. Cross-talk between angiotensin II and interleukin-6 nuclear signaling. Fournal of Biological Chemistry 270 19059-19065.

Bossone SA, Asselin C, Patel AJ \& Marcu KB 1992 MAZ, a zinc finger protein, binds to $\mathrm{c}-\mathrm{MYC}$ and $\mathrm{C} 2$ gene sequences regulating transcriptional initiation and termination. PNAS $897452-7456$.

Bradford MM 1976 A rapid and sensitive method for the quantitation of microgram quantities of protein utilizing the principle of protein-dye binding. Analytical Biochemistry 72 248-254.

Chin E, Zhou J \& Bondy CA 1992 Renal growth hormone receptor gene expression: relationship to renal insulin-like growth factor system. Endocrinology 131 3061-3066.

Curnow KM, Pascoe L, Davies E, White PC, Corvol P \& Clauser E 1995 Alternatively spliced human type 1 angiotensin II receptor mRNAs are translated at different efficiencies and encode two receptor isoforms. Molecular Endocrinology 9 1250-1262.

Guo D-F \& Inagami T 1994 The genomic organization of the rat angiotensin II receptor $\mathrm{AT}_{1 \mathrm{~B}}$. Biochimica et Biophysica Acta 1218 91-94.

Guo D-F, Furuta H, Mizukoshi M \& Inagami T 1994 The genomic organization of human angiotensin II type 1 receptor. Biochemical and Biophysical Research Communicaions 200 313-319.

Guo D-F, Uno S, Ishihata A, Nakamura N \& Inagami T 1995 Identification of a cis-acting glucocorticoid responsive element in the rat angiotensin II type $1 \mathrm{~A}$ promoter. Circulation Research 77 249-257.

Hoffman DM, Crampton L, Sernia C, Nguyen TV \& Ho KK 1996 Short-term growth hormone (GH) treatment of GH-deficient adults increases body sodium and extracellular water, but not blood pressure. Fournal of Clinical Endocrinology and Metabolism 81 1123-1128.

Kerrigan LA, Croston GE, Lira LM \& Kadonaga JT 1991 Sequence-specific transcriptional antirepression of the Drosophila Kruppel gene by the GAGA factor. Fournal of Biological Chemistry 266 574-582.

Le Cam A, Pantescu V, Paquereau L, Legraverend C, Fauconnier G \& Asins G 1994 cis-Acting elements controlling transcription from rat serine protease inhibitor $2 \cdot 1$ gene promoter. Characterization of two growth hormone response sites and a dominant purine-rich element. Fournal of Biological Chemistry 269 21532-21539.

Lee H, Kraus KW, Wolfner MF \& Lis JT 1992 DNA sequence requirements for generating paused polymerase at the start of hsp70. Genes and Development 6 284-295.

Lee S \& Greenspan DS 1995 Transcriptional promoter of the human alpha $1(\mathrm{~V})$ collagen gene (COL5A1). Biochemical Fournal 310 15-22.

Legraverend C, Simar-Blanchet AE, Paul C, Sotiropoulos A, Finidori J \& Le Cam A 1996 A novel growth hormone response element unrelated to STAT (signal transducer and activator of transcription)-binding sites is a bifunctional enhancer. Molecular Endocrinology 10 1507-1518.

Lu Q, Wallrath LL, Granok H \& Elgin SC 1993 (CT)n (GA)n repeats and heat shock elements have distinct roles in chromatin structure and transcriptional activation of the Drosophila hsp26 gene. Molecular and Cellular Biology 13 2802-2814.
Maniatis T, Goodbourn S \& Fischer JA 1987 Regulation of inducible and tissue-specific gene expression. Science 236 $1237-1245$.

Mujais SK, Kauffman S \& Katz AI 1986 Angiotensin II binding sites in individual segments of the rat nephron. Fournal of Clinical Investigation 77 315-318.

Ogbourne S \& Antalis TM 1998 Transcriptional control and the role of silencers in transcriptional regulation in eukaryotes. Biochemical fournal 331 1-14.

Pages G, Stanley ER, Le Gall M, Brunet A \& Pouyssegur J 1995 The mouse p44 mitogen-activated protein kinase (extracellular signal-regulated kinase 1) gene. Genomic organization and structure of the 5 '-flanking regulatory region. Fournal of Biological Chemistry 270 26986-26992.

Racusen LC, Monteil C, Sgrignoli A, Lucskay M, Marouillat S, Rhim JGS \& Morin J 1997 Cell lines with extended in vitro growth potential from human renal proximal tubule: characterization, response to inducers, and comparison with established cell lines. Fournal of Laboratory and Clinical Medicine 129 318-329.

Raizada MK, Phillips MI \& Sumners C (Eds) 1996 Recent Advances in Angiotensin II Receptors, edn 1. New York: Plenum Press.

Regitz-Zagrosek V, Neuss M, Holzmeister J, Warnecke C \& Fleck E 1996 Molecular biology of angiotensin receptors and their role in human cardiovascular disease. Fournal of Molecular Medicine 74 233-251.

Sambrook J, Fritsch EF \& Maniatis T 1989 Molecular Cloning: a Laboratory Manual. Cold Spring Harbor, New York: Cold Spring Harbor Laboratory.

Simar-Blanchet AS, Legraverend C, Thissen JP \& Le Cam A 1998 Transcription of the rat serine protease inhibitor $2 \cdot 1$ gene in vivo: correlation with GAGA box promoter occupancy and mechanism of cytokine-mediated down-regulation. Molecular Endocrinology 12 391-404.

Su B, Martin MM, Beason KB, Miller PJ \& Elton TS 1994 The genomic organization and functional analysis of the promoter for the human angiotensin II type 1 receptor. Biochemical and Biophysical Research Communications 204 1039-1046.

Takayanagi R, Ohnaka K, Sakai Y, Ikuyama S \& Nawata H 1994 Molecular cloning and characterization of the promoter for human type-1 angiotensin II receptor gene. Biochemical and Biophysical Research Communications 200 1264-1270.

Takeuchi K, Alexander RW, Nakamura Y, Tsujino T \& Murphy TJ 1993 Molecular structure and transcriptional function of the rat vascular AT1a angiotensin receptor gene. Circulation Research 73 612-621.

Thomas WG, Baker KM, Motel TJ \& Thekkumkara TJ 1995 Angiotensin II receptor endocytosis involves two distinct regions of the cytoplasmic tail. Fournal of Biological Chemistry $27022153-22159$.

Weber JA, Taxman DJ, Lu Q \& Gilmour DS 1997 Molecular architecture of the hsp70 promoter after deletion of the TATA box or the upstream regulation region. Molecular and Cellular Biology 17 3799-3808.

Wyse B \& Sernia C 1997 Growth hormone regulates AT-1a angiotensin receptors in astrocytes. Endocrinology 138 $4176-4180$.

Wyse B, Waters M \& Sernia C 1993 Stimulation of the renin-angiotensin system by growth hormone in Lewis dwarf rats. American Fournal of Physiology 265 E332-E339.

RECEIVED 29 September 1999 